\title{
EFFICACY OF SEAWEED EXTRACT ON CHILLI LEAF CURL VIRUS
}

\author{
Sugandhika M.G.G. ${ }^{1}$, Pakeerathan K. ${ }^{1}{ }^{*}$ and Fernando W.M.K. ${ }^{2}$ \\ ${ }^{1}$ Department of Agricultural Biology, Faculty of Agriculture, University of Jaffna \\ ${ }^{2}$ Field Crops Research and Development Institute, Department of Agriculture, Mahailluppallama, Sri Lanka \\ *Corresponding Author: pakeerathank@univ.ifn.ac.lk (https://orcid.org/0000-0001-7373-3481) \\ Received: 05.07.2021; Accepted: 15.09.2021; Published: 05.11.2021
}

\begin{abstract}
The important cash crop of Chilli's (Capsicum annum L) production and yield is hampered by Chilli Leaf Curl Virus Disease (CLCVD) in Sri Lanka. To manage CLCVD several insecticides were promised against the vectors of CLCV. Indiscriminate use of insecticides created unwanted human health hazards. The current trends in plant pathology intend to boost the immunity of the host to increase the resistance against pathogens. Therefore, this study was conducted to investigate the efficacy of Sea-Weed Extract (SWE) to manage CLCVD. The chilli variety Vijaya was selected for this experiment with five treatments and a non-treated control, which were arranged in RBCD. Data on growth parameters, yield, aphid severity, and CLCV disease severity Index (DSI) were measured and subjected to ANOVA in SAS and Tukey's HSD multiple comparison test was used to identify the best treatment combination at $P<0.05$. The results showed that first application of Sea-Weed Extract (SEW) at 15 days after planting with subsequent application of SWE at 15 days interval + application of insecticides at 10-15 days interval (T4) significantly lowered the CLCV DSI of 40.24\%, less aphid severity index of $5.16 \%$ with the highest chilli yield of $436.8 \mathrm{~kg} / \mathrm{ha}$. The investigation concluded that SWE induces plant immunity but no effect on vector control. Therefore, SWE with recommended insecticides is better to increase the immunity of plants for the effective management of CLCVD.
\end{abstract}

Keywords: Aphid, Chilli, Chilli Leaf Curl Virus, Insecticide, Sea-Weed Extract

\section{INTRODUCTION}

Chilli (Capsicum annuum L.), belongs to the family of Solanaceae, is one of the most important spice crops of cuisines of tropical and subtropical countries, native to South America (Thakur et al., 2018). Chilli is the fourth major crop cultivated in the world for its fruits, which are consumed in green as well as ripe dried form by people due to its pungency (Kumar \& Kumar, 2017). Chilli is cultivated as a cash crop, mainly in the dry zone especially in the north-central province and the intermediated zones of Sri Lanka. Per capita consumption of dry chilli is estimated as $2.84 \mathrm{~kg}$ per year and Sri Lanka requires 60,000 metric tons of dried chilli and 63,000 metric tons of green chilli per year (https://www.doa.gov.lk/ETC/index.php/en/crop/17 8-2-4). In the year of 2018, the total extent of the chilli cultivation was $13553 \mathrm{ha}$, the total production was 79003 tons, and average yield was 5.83 tons/ha in Sri Lanka (AgStat,2019). In 2020, the green chilli cultivation extend, total production and average yield were declined to 10,981ha, 60,593 tons, and 5.52tons/ha, respectively (AgStat, 2020). This $10-12 \%$ production loss within a year due to farmers who are cultivating Chilli in Sri Lanka face several pest and diseases attacks that are inflicting severe yield reduction. Chilli leaf curl virus disease (CLCVD) is one of the catastrophic diseases of chilli crop and it causes severe yield loss, which may be up to $100 \%$ if not properly monitored and managed.

The CLCVD in chilli is caused by Begomovirus belonging to the family of Geminiviridae and CLCVD has become highly important in recent years in Sri Lanka as a new variant of CLCV attacking in Sri Lanka, is called Chilli leaf curl Sri Lanka virus (ChiLCSLV) (Senanayake et al., 2012). Chilli leaf curl virus is transmitted by whitefly, Bemisia tabaci. Symptoms of the chilli leaf curl virus disease are severe leaf curl with cupshaped, upward curling leaves, yellowing, and stunted plant growth (Briddon et al., 2010).

Different methods are being used to control CLCVD, such as cultural, physical, mechanical, biological, and chemical methods. There are no direct chemicals to control any virus diseases, but vectors who are transmitting respective virus diseases are being targeted directly to control using chemicals. Insecticides have a negative impact on human health and the environment. Injudicious use of insecticides in both doses and types often cause 
problems because they can increase production costs and leave residuals on products (Astuti et al., 2013). The utilization of non-hazardous materials such as plants extracts, seaweed extracts, and biocontrol agents and their effectiveness are being investigated. The seaweed extracts have achieved much wider acceptance as "plant bio-stimulants". Seaweeds belong to the algae group, and marine seaweed belongs to the families Chlorophyceae (green), Rhodophyceae (Red), and Phaeophyceae (brown). The colour of algae depends on the pigment present in algae species. The green colour of green algae is due to the presence of Chlorophyll as in higher plants. The Phaeophytes algae are brown due to the dominance of xanthophylls and fucoxanthin pigments, and the reason for red colour in Rodophytes is due to phycoerythrin pigment (Abad et al., 2011).

Usually, seaweed extracts, even at low concentrations, can induce an array of plant responses, such as increasing plant growth, improving flowering \& yield, improved quality of products, and enhanced nutritional content of the edible product (Raj et al., 2018). The application of some seaweed extracts (SWE) has also been reported to enhance plant tolerance to a wide range of abiotic stresses i.e., drought, salinity, and temperature extremes. Several research findings are available to demonstrate the beneficial effect of seaweed products on plant seed germination, enhanced resistance to pathogens and abiotic stress and improved post-harvest quality (Jayaraj et al., 2011). Based on the above criticisms, an investigation was carried out to evaluate the efficacy of Seaweed extract on CLCVD and the growth and yield parameters of the chilli.

\section{METHODOLOGY}

The study was conducted during the 2019/2020 Maha season as a field experiment at the Field Crops Research and Development Institute (FCRDI) located in $8^{\circ} 6^{\prime} 0^{\prime \prime} \mathrm{N}$ and $80^{\circ} 27^{\prime} 0^{\prime \prime} \mathrm{E}$, Maha-Illuppallama, North Central Province, Sri Lanka. The nursery and field preparation for chilli was performed according to the Department of Agriculture recommendation. Vijaya variety was chosen as testing material because of its higher susceptible to the CLCVD, and moderately CLCV resistant $K A 2$ chilli variety was used only for CLCVD comparison with Vijaya chilli variety.

\section{Nursery Management}

Nursery bed of $2 \mathrm{mx} 1 \mathrm{~m}$ was prepared and sterilized by burning method using paddy straw and paddy husk. Well rotten cow dung (8 t ac-1) was incorporated into the sterilized nursery bed after the removal of ash. Water was applied and left for few hours. Chilli seeds of the Vijaya variety and KA2 variety (only for CLCV comparison) were treated with fungicides and sown at the spacing of $10 \mathrm{~cm}$ between rows with $1 \mathrm{~cm}$ depth. A thin, dry paddy straw layer was used to cover nursery beds as mulch to prevent insect pests. Paddy straw mulch was removed after 7-10 days of seeds germination.

\section{Field trial}

The field was ploughed $45 \mathrm{~cm}$ depth with a disc plough and soil was pulverized using a rotavator to make fine-textured soil. The size of the experimental plot was $4.5 \times 4.8 \mathrm{~m}$. Ridges were made with $60 \mathrm{~cm}$ spacing for each treatment. Drains with the $30 \mathrm{~cm}$ width and bunds with $40 \mathrm{~cm}$ width were prepared for basin irrigation in between rows and plots, respectively. Three days before transplanting, decomposed cow dung and basal fertilizer were applied to the plots according to the Department of Agriculture (DOA) recommendation (Table 1). Twenty-one days old chilli seedlings were transplanted with one plant per hill at the spacing of $60 \times 45 \mathrm{~cm}$. All the other cultural practices (weeding, irrigation, etc.) were followed according to the recommendation of DOA for chilli cultivation.

Table 1: Fertilizer recommendation for chilli

\begin{tabular}{cccc}
\hline $\begin{array}{c}\text { Time of } \\
\text { Application }\end{array}$ & \multicolumn{3}{c}{ Rate of Application (kg/ ha) } \\
\hline & Urea & TSP & MOP \\
\cline { 2 - 4 } Basal dressing & - & 100 & 50 \\
$1^{\text {st }}$ top dressing & 100 & - & - \\
$2^{\text {nd }}$ top dressing & 125 & - & - \\
$3^{\text {rd }}$ top dressing & 125 & - & 50 \\
$4^{\text {th }}$ top dressing & 125 & - & - \\
\hline
\end{tabular}

(Source: DOA,

https://www.doa.gov.lk/FCRDI/index.php/en/crop/34chilli)

The seaweed extract AG Fort health boosterTM (composition: Processed Macroalgal extract, natural acidity regulators: $24 \% \quad \mathrm{~W} / \mathrm{W}$ mini stabilizer and aqueous diluent $76 \% \mathrm{~W} / \mathrm{W}$ ) produced by SUPR pathways ${ }^{\mathrm{TM}}$ Technology is being marketed by Browns Agri Solutions Pvt (Ltd) was received for pilot trials. The seaweed extract AG Fort health booster ${ }^{\mathrm{TM}}$ dosage was prepared as per the recommendation of the producer $(300 \mathrm{~mL} / \mathrm{Ac}$ or $1.5 \mathrm{~mL} / \mathrm{L}$ ), and treatments were administrated in combinations as described in Table 2 . 
Table 2: Details of the treatments used in the study

\begin{tabular}{|c|c|}
\hline $\begin{array}{l}\text { Treatment } \\
(\mathbf{T})\end{array}$ & Application details \\
\hline T1 & $\begin{array}{l}1^{\text {st }} \text { application of SWE } 10 \text { DAP }+2^{\text {nd }} \text { and } \\
3^{\text {rd }} \text { spraying of SWE at } 15 \text { days interval. }\end{array}$ \\
\hline $\mathbf{T 2}$ & $\begin{array}{l}1^{\text {st }} \text { application of SWE } 15 \mathrm{DAP}+2^{\text {nd }} \text { and } \\
3^{\text {rd }} \text { spraying of SWE at } 15 \text { days interval. }\end{array}$ \\
\hline $\mathbf{T 3}$ & $\begin{array}{l}1^{\text {st }} \text { application of SWE } 10 \text { DAP }+2^{\text {nd }} \text { and } \\
3^{\text {rd }} \text { spraying of SWE at } 15 \text { days interval } \\
+ \text { Application of insecticides at } 12 \text { days } \\
\text { interval. }\end{array}$ \\
\hline T4 & $\begin{array}{l}1^{\text {st }} \text { application of SWE } 15 \text { DAP }+2^{\text {nd }} \text { and } \\
3^{\text {rd }} \text { spraying of SWE at } 15 \text { days interval } \\
+ \text { Application of insecticides at } 12 \text { days } \\
\text { interval. }\end{array}$ \\
\hline T5 & $\begin{array}{l}\text { Application of insecticides at } 12 \text { days } \\
\text { interval. }\end{array}$ \\
\hline T6 & Control. \\
\hline
\end{tabular}

\section{Chilli Leaf Curl Virus Severity}

Severity of CLCV was rated using 24 plants/ plot according to the scale of $0-4$, where $0=\mathrm{No}$ symptoms; $1=1-5 \%$ of the plant showing CLCV symptoms; $2=6-25 \%$ of the plant showing CLCV symptoms; $3=26-50 \%$ of the plants showing CLCV symptoms; $4=51-100 \%$ of the plants showing CLCV symptoms, after 15 weeks of sawing. The disease severity index was calculated by the formula given below (Banerjee and Kalloo, 1987).

Disease severity index $(\mathrm{DSI})=\frac{\sum(V X n)}{N X Z} X 100 \%$

DSI $=$ Severity index; $\mathrm{V}=$ Score value; $\mathrm{n}=$ Number of plants having the same score

$\mathrm{N}=$ Total number of plants observed; $\mathrm{Z}=$ Maximum scale number

\section{Aphid damage severity}

Table 3: Aphid severity rating

\begin{tabular}{ccl}
\hline Rating & $\begin{array}{c}\text { Number of } \\
\text { aphids }\end{array}$ & \multicolumn{1}{c}{ Appearance } \\
\hline $\mathbf{0}$ & 0 & No infestation \\
$\mathbf{1}$ & $1-4$ & A few individual aphids \\
$\mathbf{3}$ & $5-20$ & A few isolated colonies \\
$\mathbf{5}$ & $21-100$ & Several small colonies \\
$\mathbf{7}$ & $101-500$ & Large, isolated colonies \\
$\mathbf{9}$ & $>500$ & Large continues colonies \\
\hline
\end{tabular}

(Litsinger et al., 1977)

Aphid damage was observed in the trials visually within treatments. Hence aphid damage severity was calculated following the standard method of 0 9 scale (Table 3) proposed by the Litsinger et al., 1977.

The Aphid Severity Index was calculated using the same formula used to calculate CLCV.

\section{Data collection and Statistical analysis}

All the data on disease severity index, aphid severity index, number of days for 50\% flowering, growth and yield were subjected to ANOVA under SAS 9.4 system and Tukey's HSD multiple comparison test was used to identify the best treatment combination at $P<0.05$.

\section{RESULTS AND DISCUSSION}

The application of insecticides is the most commonly used method by farmers to control the leaf curl complex in Sri Lanka. However, applications of insecticides cause problems such as environmental pollution, hazarding to non- targeted organisms, etc. The results of the investigation carried out to induce the plant immunity to reduce the CLCV attack are summarized.

The CLCV disease severity increased along with the weeks after planting, but the rate of increase decreased after administration of different treatments in combination (Figure 1). The CLCV disease severity was significantly different among different treatments at $P<0.05$. The investigated variety Vijaya showed significantly lower DSI \% of 40.24 and 43.07 in $1^{\text {st }}$ application of SWE 10 DAP $+2^{\text {nd }}$ and $3^{\text {rd }}$ spraying of SWE at 15 days interval + Application of insecticides at 12 days interval (T3), and $1^{\text {st }}$ application of SWE 15 DAP $+2^{\text {nd }}$ and $3^{\text {rd }}$ spraying of SWE at 15 days interval + Application of insecticides at 12 days interval (T4) (Figure 1), respectively, compared to the other treatments. Disease severity indexes in $1^{\text {st }}$ application of SWE $10 \mathrm{DAP}+2^{\text {nd }}$ and $3^{\text {rd }}$ spraying of SWE at 15 days interval (T1), $1^{\text {st }}$ application of SWE $15 \mathrm{DAP}+2^{\text {nd }}$ and $3^{\text {rd }}$ spraying of SWE at 15 days interval (T2), Application of insecticides at 12 days interval (T5) and control were $74.00 \%, 80.07 \%$ and $69.02 \%$, and $100 \%$, respectively. This finding indicated that sole application of SWE and insecticides are less effective than combined application of SWE with insecticides. The CLCV disease severity was significantly less (highly significant $60 \%$ in control) in $K A-2$ variety (moderately resistant to CLCV) comparison to variety Vijaya (susceptible to CLCV) in similar treatment combinations (Figure 2.) The findings indicated that more prominent results could be obtainable when using the SWE to the varieties that are already genetically resistant.

The growth and reproductive parameters were not affected by the application of SWE, whereas yield was significantly different among treatment. Treatment 1st application of SWE 10 DAP + 2nd 
and 3rd spraying of SWE at 15 days interval + Application of insecticides at 12 days interval (T3) (413.2 kg/ha), and $1^{\text {st }}$ application of SWE 15 DAP $+2^{\text {nd }}$ and $3^{\text {rd }}$ spraying of SWE at 15 days interval + Application of insecticides at 12 days interval (T4) $(436.8 \mathrm{~kg} / \mathrm{ha})$ showed highest significant mean yield compared to the control $(252.3 \mathrm{~kg} / \mathrm{ha})$ at $P$ $<0.05$. In comparison to application of insecticides at 12 days interval (T5), combined application of SWE and insecticides effectively increased the yield while reducing disease incidence.

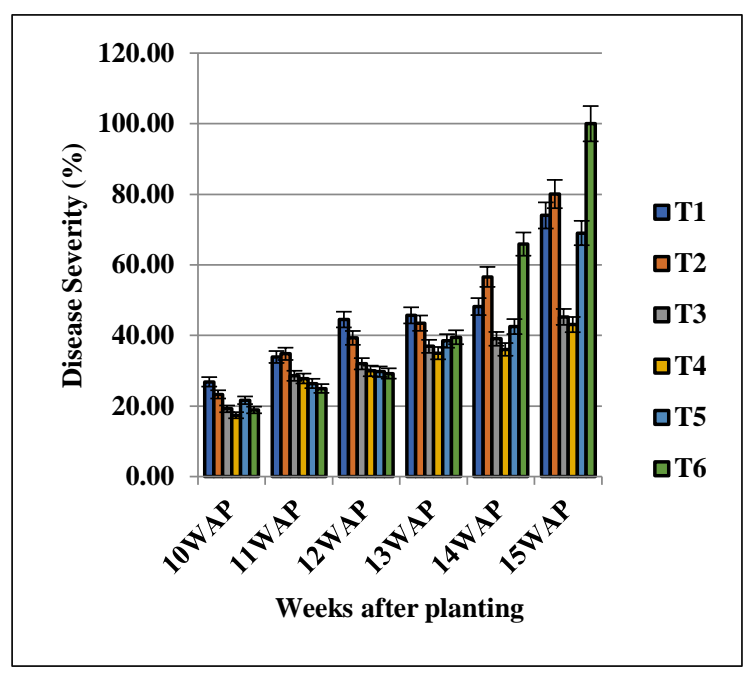

Figure 1: Chilli leaf curl virus disease progress from 10th week after planting in Vijaya

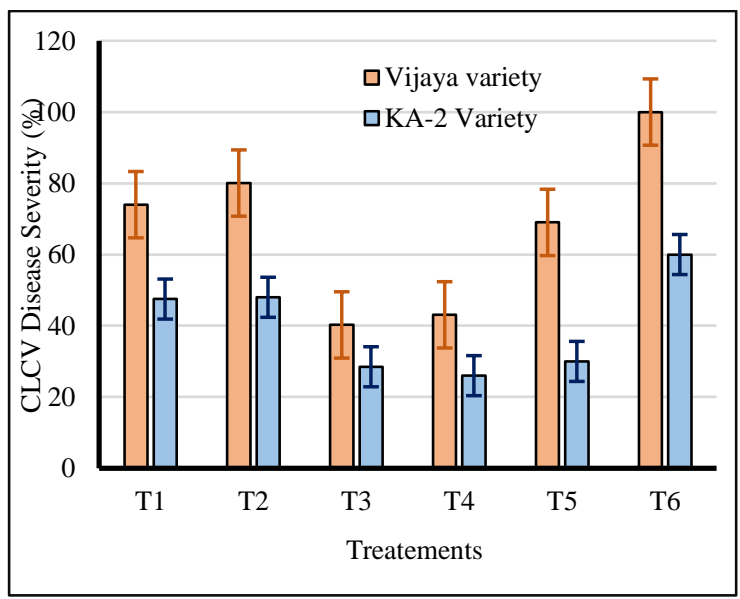

Figure 2: Comparison of Chilli leaf curl disease severity between Vijaya and KA-2 at 15 weeks after planting

In the Vijaya variety, there is a significant difference in aphid severity index among the different treatments (Table 4). When compared to the control treatment $(16.47 \%)$, 1st application of SWE $10 \mathrm{DAP}+2 \mathrm{nd}$ and 3rd spraying of SWE at 15 days interval + Application of insecticides at 12 days interval (T3) (5.23\%), and $1^{\text {st }}$ application of SWE $15 \mathrm{DAP}+2^{\text {nd }}$ and $3^{\text {rd }}$ spraying of SWE at 15 days interval + Application of insecticides at 12 days interval (T4) (5.56\%) showed a low mean value of the aphid severity index. Among the treatments, the variety treated with insecticides showed higher aphid severity index of $8.67 \%$ than 1st application of SWE 10 DAP + 2nd and 3rd spraying of SWE at 15 days interval + Application of insecticides at 12 days interval (T3), and $1^{\text {st }}$ application of SWE $15 \mathrm{DAP}+2^{\text {nd }}$ and $3^{\text {rd }}$ spraying of SWE at 15 days interval + Application of insecticides at 12 days interval (T4). The study concluded that applying seaweed extract with insecticides could be effective than sole application of insecticides to control pest and diseases.

Table 4: Mean values of aphid severity index, number of days for 50\% flowering, plant height, and yield of Vijaya chilli variety

\begin{tabular}{ccccc}
\hline Treatment & $\begin{array}{c}\text { Aphid } \\
\text { severity } \\
\text { Index } \\
(\%)\end{array}$ & $\begin{array}{c}\text { Number } \\
\text { of days } \\
\text { for } \mathbf{5 0 \%} \\
\text { flowering }\end{array}$ & $\begin{array}{c}\text { Plant } \\
\text { height } \\
(\mathbf{c m})\end{array}$ & $\begin{array}{c}\text { Yield } \\
(\mathbf{k g} / \mathbf{h a})\end{array}$ \\
\hline $\mathrm{T} 1$ & $14.46^{\mathrm{a}}$ & $45 \pm 1^{\mathrm{a}}$ & $32.51^{\mathrm{a}}$ & $330.4^{\mathrm{c}}$ \\
$\mathrm{T} 2$ & $06.60^{\mathrm{b}}$ & $45 \pm 1^{\mathrm{a}}$ & $31.56^{\mathrm{a}}$ & $358.9^{\mathrm{c}}$ \\
$\mathrm{T} 3$ & $05.23^{\mathrm{c}}$ & $44 \pm 1^{\mathrm{a}}$ & $33.48^{\mathrm{a}}$ & $413.2^{\mathrm{a}}$ \\
$\mathrm{T} 4$ & $05.16^{\mathrm{c}}$ & $42 \pm 1^{\mathrm{a}}$ & $32.34^{\mathrm{a}}$ & $436.8^{\mathrm{a}}$ \\
$\mathrm{T} 5$ & $08.67^{\mathrm{b}}$ & $44 \pm 1^{\mathrm{a}}$ & $37.93^{\mathrm{a}}$ & $396.0^{\mathrm{b}}$ \\
$\mathrm{T} 6$ & $16.47^{\mathrm{a}}$ & $48 \pm 1^{\mathrm{a}}$ & $29.32^{\mathrm{a}}$ & $252.3^{\mathrm{d}}$ \\
\hline $\mathrm{CV} \%$ & $38.2^{2}$ & 6.3 & 9.3 & $34.7^{2}$ \\
\hline Mean values & with & the & same & alphabets are not \\
significantly different according to the Tukey's HSD \\
multiple comparison test at $95 \%$ confidence interval
\end{tabular}

The seaweed extracts made from different raw materials, and procedures are attributed to several beneficial effects such as biotic and abiotic stress tolerance, increased nutrient uptake, and improve quality of products (Raj et al., 2018). Moreover, the biologically active compounds like polysaccharides, proteins, polyunsaturated fatty acids, pigments, polyphenols, minerals, plant growth hormones and other in the algal extracts mainly boost the antibacterial activity, scavenging of free radicals, host defense activity etc. Therefore, the yield of the plants increased and it highly recommended to use as liquid fertilizer even in poor quality soil (Narayasamy et al., 2020; Chojnacka at al., 2012). Abetz (1980) reviewed that cytokinins are a major active constituent of seaweed extracts and that the extracts may increase frost resistance, increase nutrient uptake and changes in plant chemical composition, increase disease and pest resistance, increase yields and improve seed germination.

Venkates (2016) stated that the red seaweed extracts of Kappaphycus alvarezii-1 (0.4\%) 
reduced the percentage of disease index (PDI) of Cucumber Mosaic Virus (CMV) in gherkins in the field experiments. Pushpa et al., (2018) reported the delay in appearance of Papaya Ring Spot Virus (PRSV) symptoms in papaya plants treated with $K$. alvarezii (0.4\%). Kavyashri and Nagaraju (2019) recorded that there was a significant reduction in the severity of CMV disease in chilli treated with $K$. alvarezii as a biotic inducer. Seaweed extracts have been highly reported to enhance plant growth, vigour, and productivity and improve resistance to pests and diseases (Raj et al., 2018). The current findings are in agreement with the previous findings.

The application of SWE triggers the plant defense genes very effectively than the water applied as acontrol, and suppresses the fungal diseases Alternaria radicina and Botrytis cinerea than Salicylic acid. Application of SWE in carrot exhibited the overexpressed level of protein products of genes such as pathogenesis-related protein I $(P R-1)$, chitinase, lipid transfer protein (Ltp), phenylalanine ammonia-lyase (Pal), chalcone synthase, non-expressing pathogenesis-related protein $(N P R-1)$ and pathogenesis-related protein 5 $(P R-5)$ than the untreated control explained that SW enhances disease resistance in plants through induction of defense genes or proteins (Jayaraj et al., 2008).

Devi and Mani (2015) reported that the application of $K$. alvarezii sap with $100 \%$ recommended dosage of fertilizer to rice plants increased in growth, yield attributes, quality and chlorophyll content. Application of $K$. alvarezii $(0.4 \%)$ and $P$. fluorescens $(0.6 \%)$ significantly improved plant yield under field condition (Kavyashri and Nagaraju, 2019). Arthur (2003) reported that capsicum yield could be increased by using a different concentrated mixer of SWE. These evidences tally with the current findings. Stephenson (1966) further proved that application hydrolyzed seaweed on crops in two weeks interval significantly reduced the severity of aphids, red spider mites, powdery mildew, botrytis and an unidentified complex of fungi responsible for the damping-off of seedlings.

The present study evidenced that there is no vector controlling effect of SWE. But the vector's effect has been reduced by the activation of the plant immune system. The tolerance level could be further maintained by the combined application SWE with recommended insecticides.

\section{CONCLUSIONS}

Results revealed that application of SWE with recommended insecticides at 10-15 days interval could be effective than a sole application of insecticides to reduce the severity of CLCV in Chilli. The first application of SWE at 15 days after planting is better than the first application of SWE at ten days after planting because it showed lower CLCV and high growth and yield.

\section{REFERENCES}

Abad, M.J., Bedoya, L.M. and Bermejo, P. 2011. Marine Compounds and their Antimicrobial Activities. Science against microbial pathogens: communicating current research and technological advances. In: A. Mendez-Vilas (Ed.). 1293-1306.

Abetz, P. 1980. Seaweed extracts: have they a place in Australian agriculture or horticulture?. Journal of the Australian Institute of Agricultural Science. 46(1):23-9.

AgStat (2019).

https://www.doa.gov.lk/SEPC/images/PDF/AgS tat.pdf (Accessed on 01 April 2021)

AgStat (2020).

https://www.doa.gov.lk/SEPC/images/PDF/AgS tat2020.pdf (Accessed on 12 June 2021)

Arthur, G.D., Stirk, W.A., Van Staden, J. and Scott, P. 2003. Effect of a seaweed concentrate on the growth and yield of three varieties of Capsicum annuит. South African journal of botany. 69(2):207-11.

Astuti, U.P., Wahyuni, T. and Honorita, B. 2013. Technical guidelines for the manufacture of vegetable pesticides. Agricultural Technology Assessment Center (BPTP) Bengkulu. Bengkulu.75.

Banerjee, M.K. and Kalloo, M.K. 1987. Sources and inheritance of resistance to leaf curl virus in Lycopersicon. Theoretical and Applied Genetics, 73(5), 707-710. https://doi.org/10.1007/BF00260780

Briddon, R.W., Patil, B. L., Bagewadi, B., Nawazul-Rehman, M.S. and Fauquet, C.M. 2010. Distinct evolutionary histories of the DNA-A and DNA-B components of bipartite begomoviruses. BMC Evolutionary Biology, 10(1), 1-17. https://doi.org/10.1186/1471-214810-97

Chojnacka, K., Saeid, A., Witkowska, Z. and Tuhy, L. 2012. Biologically active compounds in seaweed extracts-the prospects for the application. In The open conference proceedings journal, 3(1), 1 .

Devi, N.L. and Mani, S. 2015. Effect of seaweed saps Kappaphycus alvarezii and Gracilaria on growth, yield and quality of rice. Indian Journal of Science and Technology, 8(19), 22. 
https://www.doa.gov.lk/ETC/index.php/en/crop/17 8-2-4 (Accessed on 01 April 2021)

https://www.doa.gov.lk/FCRDI/index.php/en/crop/ 34-chilli (Accessed on 01 April 2021)

Jayaraj, J., Norrie, J. and Punja, Z.K. 2011. Commercial extract from the brown seaweed Ascophyllum nodosum reduces fungal diseases in greenhouse cucumber. Journal of Applied Phycology, 23, 353-361

Jayaraj, J., Wan, A., Rahman, M. and Punja, Z.K. 2008. Seaweed extract reduces foliar fungal diseases on carrot. Crop Protection, 10, 13601366.

https://doi.org/10.1016/j.cropro.2008.05.005

Kavyashri, V.V. and Nagaraju, N. 2019. Management of Cucumber Mosaic Virus (CMV) Disease in Chilli through Biotic Defense Inducers. International Journal of Current Microbiology and Applied Sciences, 8(1), 297-313.

Kumar, U. and Kumar, S. 2017. IDM Module for the Management of Leaf Curl Disease in Chilli. Internatinal Journal of Current Microbiology and Applied Sciences, 6(9), 2087-2091. https://doi.org/10.20546/ijcmas.2017.609.256

Litsinger, J.A., Quirino, C.B., Lumaban, M.D. and Bandong, J.P. 1977. Grain Legume Pest Complex of Three Phillipine Rice-Based Cropping System. Cropping Program, IRRI. Los Banos. Philippines, 39.

Narayasamy, S. and Jalloh, M.B. 2020. Using Seaweed Base Organic Fertilizer as Yield Booster at Volcanic Soil: Effect on Soil Quality and Yield of Patchouli (Pogostemon Cablin). Advances in Agricultural and Food Research Journal, 1(2), 24.

Pushpa, R.N., Shantamma, Pappachan, A., Manjunath, B., Sumit, B., Kumar, S., Rangaswamy, K.T., Girish, T.R. and Nagaraju, N. 2018. Molecular Characterization, Epidemiology and Management of the Papaya ring spot virus (PRSV) in Papaya under Southern Indian Conditions. International Journal of Agricultural Sciences,10(2): 50295038.

Raj, T.S., Nishanthi, P., Graff, K.H. and Suji, H.A. 2018. Seaweed extract as a biostimulant and a pathogen controlling agent in plants. International Journal of Tropical Agriculture, 36(3), 563-580.

Senanayake, D.M.J.B., Jayasinghe, J.E.A.R.M., Shilpi, S., Wasala, S.K. and Mandal, B. 2013. A new begomovirus-betasatellite complex is associated with chilli leaf curl disease in Sri Lanka. Virus genes, 46(1), 128-139.

https://doi.org/10.1007/s11262-012-0836-4

Stephenson, W.M. 1966. The effect of hydrolysed seaweed on certain plant pests and diseases. In Proceedings of the Fifth International Seaweed
Symposium, Halifax, August 25-28, pp. 405415

Thakur, H., Jindal, S.K., Sharma, A. and Dhaliwal, M.S. 2018. Chilli leaf curl virus disease: a serious threat for chilli cultivation. Journal of Plant Diseases and Protection, 125, 239-249. https://doi.org/10.1007/s41348-018-0146-8. 